\title{
EXPERIENCES WITH PHYSOSTIGMINE IN THE REVERSAL OF ADVERSE POST-ANAESTHETIC EFFECTS
}

\author{
J. Brebner ANd L. Hadley
}

SPORADIC REPORTS of physostigmine use have appeared principally from the United States, which is our present source of the drug.

Physostigmine salicylate (Antilirium ${ }^{\circledR}$ ) has been shown to be useful in the reversal of the adverse effects of belladonna alkaloids on the central nervous system, such as disorientation, violent behaviour or somnolence. ${ }^{1-10}$ This is logical in that this anticholinesterase agent is a tertiary amine (See Figure 1) capable of penetrating the blood-brain barrier, unlike our more commonly used anticholinesterases. It is harder to explain the effectiveness of physostigmine in reversing the disorientation or somnolence calsed by such diverse agents as diazepam, ${ }^{11}$ phenothiazines, ${ }^{11,12}$ tricyclic antidepressants, ${ }^{13-15}$ anti-parkinsonian drugs ${ }^{16-17}$ and, in our experience, promethazine and droperidol.

\section{PHYSOSTIGMINE}<smiles>C=C1CCC2(C)c3cc(OC(=O)N(C)C)ccc3C12</smiles><smiles>[2H][C@@H](Oc1cccc([N+](C)(C)C)c1)N(C)C</smiles>

\section{NEOSTIGMINE}

Frgure 1. Drug structures illustrating that physostigmine contains no quaternary nitrogen, unlike the commonly used anticholinesterases such as neostigmine.

We are presenting our experiences in over one hundred cases that benefitted from the use of physostigmine in the post-anaesthetic period, varying from the usual of one to three hours to the unusual of 24 hours post-operatively.

J. Brebner, M.D., Ph.D., F.R.C.P.(C) and L. Hadley, M.D., Department of Anaesthesia, Toronto General Hospital, Toronto, Ontario.

'O'Neal, Jones and Feldman, Inc., 1304 Ashby Road, St. Louis, Missouri 63132, U.S.A. 


\section{METHODS}

Patients in the recovery room were selected for treatment with physostigmine on the basis of three criteria. First, they must have received a belladonna alkaloid or neuroleptic type of agent either pre-operatively or during anaesthesia. Secondly, they had to be difficult to arouse after two hours in the recovery room or thirdly, showed disorientation and/or restlessness for more than half an hour after operation.

Initially the patients selected were given $1 \mathrm{mg}$ increments of physostigmine intravenously at 15 -minute intervals until they were conscious and orientated to time, place and person. After 50 patients had been treated, the interval was reduced to five minutes as we realized that the full effect of an individual dose was seen within this time. In addition to routine monitoring in the recovery room, blood pressure and pulse were checked immediately before and five minutes after administration of physostigmine. The patients were kept in the recovery room for one and a half hours after administration of the anticholinesterase.

\section{RESULTS}

The first 110 case reports were reviewed. A large variety of surgical procedures had been performed on these patients. Table I shows the grouping of these patients in terms of offending drugs.

The largest group of patients, 54 in number, had received scopolamine (Hyoscine(B) either intramuscularly or intravenously in doses ranging from $0.2 \mathrm{mg}$ to $0.6 \mathrm{mg}$. All were drowsy to comatose, except for three who were disorientated and thrashing around. The age range of these patients was from 17 to 73 years with 48 per cent being in the over-50 group.

The female to male ratio was $2: 1$. Out of 52 patients, nine required only physostigmine $1 \mathrm{mg}$ intravenously to make them awake and orientated, five required more than $2 \mathrm{mg}$, and the rest responded to $2 \mathrm{mg}$ of physostigmine. One patient showed only slight improvement and another had no change in status.

There was a group of nine patients who, according to the chart, had received only atropine as a possible offending agent. Female to male ratio was $2: 1$ and twothirds of them were over 60 years of age. All these patients were aroused with 1 to $2 \mathrm{mg}$ of physostigmine administered intravenously.

TABLE I

Physostigmine Post-or

\begin{tabular}{lcc}
\hline \multicolumn{1}{c}{$\begin{array}{c}\text { Offending } \\
\text { Agents }\end{array}$} & No. of cases & $\begin{array}{c}\text { Ratio } \\
\text { F/M }\end{array}$ \\
\hline 1. Scopolamine & 54 & $2: 1$ \\
& $\begin{array}{c}\text { Age range } 17 \text { to } 73 \text { years } \\
48 \% \text { over age } 50 \text { years } \\
9\end{array}$ & \\
2. Atropine & $6 / 9$ over age 60 years & $2: 1$ \\
3. Neuroleptic & Mgents & $\begin{array}{l}\text { Majority over age } 50 \\
\text { Total } 110 \text { cases }\end{array}$ \\
\hline
\end{tabular}


The last group of patients consisted of 47 people who had received promethazine, droperidol or diazepam alone or in conjunction with hyoscine or with each other. Again the majority of the group were over 50 years old. However, the sex ratio was 1:1. Three of the patients had had muscle biopsies to test for malignant hyperthermia trait. These three had received massive amounts of droperidol, and diazepam. They all fell asleep again after an hour and remained extremely drowsy into the next day.

The side effects encountered in the 110 patients consisted of transient nausea and vomiting in six cases, of whom two also sweated. Instead of the expected bradycardia, tachycardia or no change in heart rate usually occurred. Blood pressure and pulse usually increased.

The effect of a single intravenous dose of physostigmine is seen in three to five minutes. If left alone, the patient will first increase rate and depth of respirations and then possibly stir a little. If the dose is fully effective he will then quietly open his eyes and become fully conscious. At this stage he may complain of pain. The duration of effectiveness of an intravenous dose against the mixed agents was three-quarters to one hour. This group of patients often became drowsy again.

To illustrate the usefulness of physostigmine in the recovery room and afterwards, a few case reports will be discussed.

\section{Case 1:}

A healthy 45-year-old male who weighed $80 \mathrm{~kg}$ received pantopon $15 \mathrm{mg}$ and hyoscine $0.2 \mathrm{mg}$ intramuscularly one hour prior to bronchoscopy and mediastinoscopy. He was acting a little strangely before the operation but was quite bizarre afterwards, sitting up in a surgilift, chewing the infusion pole. It required four increments of physostigmine $1 \mathrm{mg}$ intravenously at five-minute intervals before he was completely rational and co-operative. Each increment administered improved his tractibility and rationality.

\section{Case 2:}

A 52-year-old male with chronic renal failure required repetition of laparotomy for repair of a ruptured anastomosis of bowel. He was alert but apprehensive and begged the anaesthetist to make sure that he was properly asleep for this operation. The anaesthetist obliged by giving him an intravenous bolus of hyoscine 0.6 $\mathrm{mg}$, followed by sodium thiamylal $425 \mathrm{mg}, \mathrm{N}_{2} \mathrm{O} / \mathrm{O}_{2}-4 / 2 \mathrm{l} / \mathrm{min}$, succinycholine $100 \mathrm{mg}$, pancuronium $6 \mathrm{mg}$ and fentanyl to a total of $0.3 \mathrm{mg}$. At the end of two hours his paralysis was reversed with atropine $1.2 \mathrm{mg}$ and neostigmine $2.5 \mathrm{mg}$. $\mathrm{He}$ breathed well but remained unconscious. Because of his moribund mien and the anxiety of the nurses, treatment with physostigmine was started at 40 minutes after operation. The course of events is shown in Table II.

The respiratory rate was quite adequate at the start. With the first dose of physostigmine $1 \mathrm{mg}$ there was very slight drop in heart rate and blood pressure. When he began to respond to loud shouting, shaking and painful stimuli, blood pressure went up. A total of $6 \mathrm{mg}$ of physostigmine was used before the patient became fully conscious.

The diagnostic as well as therapeutic use of physostigmine will be illustrated with the next case. 
TABLE II

Intravenous Physostigmine - Chronic Renal Failure

Hyoscine 0.6 MG I.V. at 1640 COMATOSE POST-OP 1845

\begin{tabular}{|c|c|c|c|c|c|}
\hline Time & $\begin{array}{l}\text { Physostigmine } \\
\text { (mg) }\end{array}$ & $\mathrm{B} / \mathrm{P}$ & H.R. & R.R. & Response \\
\hline 1920 & - & $144 / 84$ & 95 & 18 & Comatose \\
\hline 1923 & 1 & $134 / 90$ & 90 & 18 & Opened 1 eye to strong stimuli \\
\hline 1930 & 1 & $152 / 98$ & 95 & 18 & Opened both eyes to strong stimuli \\
\hline 1938 & 2 & $152 / 98$ & 95 & 24 & $\begin{array}{l}\text { Opened eyes sponta neously, in pain } \\
\text { obeying commands }\end{array}$ \\
\hline 2115 & 一 & $152 / 98$ & 95 & 24 & Talking clearly but still confused \\
\hline $\begin{array}{l}2120 \\
2245\end{array}$ & \multicolumn{5}{|c|}{$\begin{array}{l}2 \mathrm{mg} 2128 \text { Completely awake and fully orientated } \\
\text { Discharged to ward }\end{array}$} \\
\hline
\end{tabular}

\section{Case 3:}

A healthy 64-year-old male executive had an internal carotid aneurysm clipped between the hours of 0815 and 1330 . The anaesthetic agents used are shown on the chart in Figure 2. At the stage of clipping of the aneurysm the enflurane concentration was. increased to 1.5 per cent for about 20 minutes to help lower his blood pressure further. Supportive ventilation was necessary on the way to the recovery room. There he was given naloxone $0.3 \mathrm{mg}$ intravenously. Five minutes later he commenced 15 minutes of seizure activity. To control this he was given

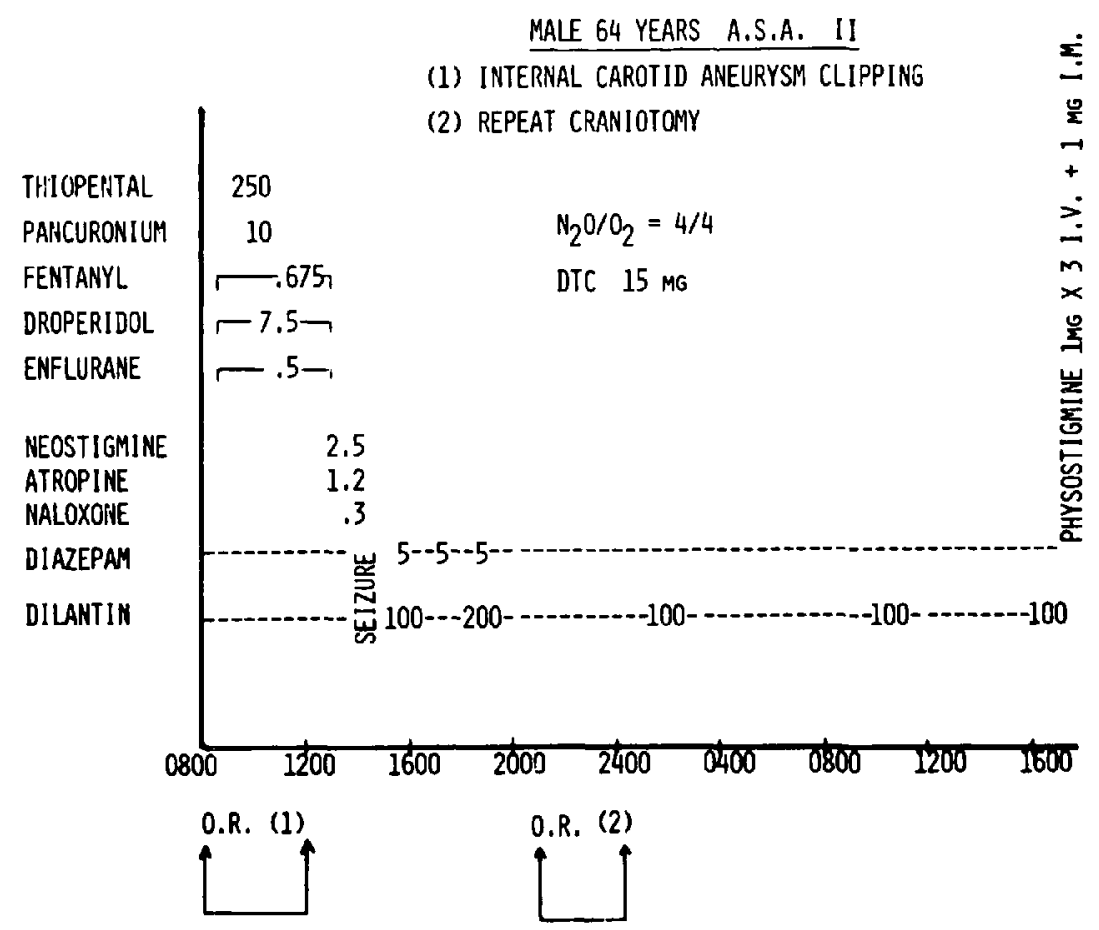

FICure 2. The chart shows the drugs used and the sequence of events occurring in Case 3. In the middle field note that very little was required to keep the patient asleep during the repent craniotomy. Physostigmine brought about a temporary return to full orientation. 
diazepam $5 \mathrm{mg}$ intravenously on three occasions over the next eight hours. Dilantin therapy was initiated as well.

Because of the history of seizures and a lack of return to consciousness, intracranial bleeding was suspected. However, at repeat craniotomy a clean surgical field was found with very little brain oedema.

At 1500 hrs the next day, a depressed neurosurgeon asked us what had been done to his patient by the anaesthetic agents. The patient was now able to walk with support, showed spontaneous disturbed behaviour, but was drowsy and would not communicate. We felt that the droperidol and diazepam the patient had received might still be having effect. Consequently the patient was given physostigmine intravenously in three increments of $1 \mathrm{mg}$ spaced five minutes apart. One mg was given intramuscularly to maintain a longer effect. He wakened and was rational. A few hours later he became drowsy again but now the neurosurgeon knew why.

\section{Drscussion}

The data in Table I verifies the well-known susceptibility of the older age groups to the belladonna alkaloids and also to neuroleptic agents. Prolonged drowsiness and disorientation were by far the commonest occurrences. Of 110 patients reported here, fewer than 10 were agitated or aggressive in behaviour. The finding of 2:1 ratio of adverse effects to the belladonna alkaloids among females is interesting. In contrast, there was an equal occurrence of the sexes where only neuroleptic drugs had been used.

Table II brings up several points which need stressing. When the first mg of physostigmine was administered, there was a slight drop of five beats per minute in heart rate and a decrease in systolic blood pressure of 10 torr. The patient improved to the stage of being only semi-comatose. The next dose of $1 \mathrm{mg}$ further improved his responses and now both blood pressure and heart rate rose. This latter response of the cardiovascular system was what we generally saw in other patients. No problem of bradycardia was encountered.

The second point to be brought out from Table II is that regarding respirations. This patient had received a narcotic during the anaesthetic and was comatose in the recovery room. However, his respiratory rate and depth were satisfactory. We feel that if respiration is adequate, there is little purpose in using an anti-narcotic agent to rouse the patient in a situation where he has received belladonna alkaloids and/or neuroleptic agents as well as narcotics. Physostigmine then becomes the drug of choice both as an antidote and as a diagnostic agent, as we used it for Case 3.

The third point is the method of administration of physostigmine. Initially the route of administration should be intravenously. In adults, $1 \mathrm{mg}(1 \mathrm{ml})$ increments created very few problems and patients seldom needed more than $2 \mathrm{mg}$ to return them to full consciousness. In the comatose patient an initial dose of $2 \mathrm{mg}$ would seem to be more appropriate. One mg increments should then be given at 10 - to 15-minute intervals until the desired effect or side effects occur. In all patients with a normal circulation the response to physostigmine was seen in three to five minutes.

In the groups of patients who received belladonna alkaloids alone, treatment with physostigmine was required only once. 
In the groups of patients who received a mixture of drugs, many frequently became drowsy again an hour after the initial treatment. They would respond to further physostigmine given at one- to two-hour intervals. The frequency of the intravenous dosage schedule is necessary because of the rapid hydrolysis of physostigmine (0.5-2 hours) by cholinesterase. ${ }^{18}$ Thus when attempting to reverse the effects of drugs such as diazepam and droperidol, which have a long duration of action, one must think in terms of repeated injections of physostigmine.

Physostigmine has been administered by both intramuscular ${ }^{14,16}$ and subcutaneous $^{1,5}$ injections. The peak effects of physostigmine occur within 30 minutes when given by these routes and duration is between one and four hours. Our own limited experience with intramuscular administration of physostigmine suggests a peak effect at about 20 minutes with a duration of approximately three hours.

The peripheral cholinergic side effects might be expected to occur more with those drugs with little anti-cholinergic effect such as diazepam or droperidol. Atropine, glycopyrrolate, or propantheline bromide in small doses, may be used to terminate the side effects. ${ }^{14}$

Physostigmine has been used to reverse the adverse central effects of the types of drugs shown in Table III. A note of caution must be inserted here. Animal data

TABLE III

Physostigmine

\begin{tabular}{l}
\hline Used to Reverse Adverse Effects of: \\
1. Neuroleptics \\
Phenothiazines \\
Droperidol \\
Diazepam \\
2. Belladona alkaloids \\
3. Anti-parkinsonian drugs \\
4. Antihistamines \\
Promethazine \\
5. Tricyclic antidepressants \\
\hline
\end{tabular}

suggest that physostigmine prolongs sleep time when used in conjunction with barbiturate or inhalational anaesthesia..$^{19,20}$ So far physostigmine would not appear to ge a general analeptic agent. It seems to act as an antidote through activation of the central cholinergic pathways. Thus in the reversal of agents acting at dopamine receptors, ${ }^{21}$ a group into which droperidol falls, the effect of physostigmine must be through an indirect pathway.

\section{SUMMARY}

Physostigmine salicylate has proved to be a very useful agent for use in the recovery room. All but two of our first 110 patients receiving it were returned to full consciousness, whether they had been comatose or agitated. In our hands it has been used to reverse the adverse central effects of tranquilizers, antihistamines and belladonna alkaloids.

\section{RÉsumé}

La physostigmine est connue comme un antidote utile lors d'empoisonnements à des agents tels les alcaloïdes de la belladonne, les tranquilisants, les anti-dépres- 
seurs tricycliques et les anti-parkinsonniens. On a souvent rencontré à la salle de réveilles problèmes de somnolence marquée, de désorientation et, parfois, d'agitation et d'agressivité chez des patients qui ont reçu des tranquilisants, des antihistaminiques ou des alcaloïdes de la belladonne avant ou pendant l'anesthésie.

La plupart des 110 cas chez qui on a utilisé la physostigmine présentaient de la désorientation et/ou de la somnolence. Six seulement présentaient de l'agitation. Quelques-uns même étaient comateux et ont été complètement réveillés. La dose habituelle nécessaire a été de 1 à $2 \mathrm{mg}$ par voie intra-veineuse. Des doses croissantes peuvent être répétées aux cinq minutes, les effets de la physostigmine se manifestant entre trois et cinq minutes après son injection intra-veineuse chez un patient avec une circulation normale. Pour les patients qui présentaient leurs symptômes secondairement aux alcaloïdes de la belladonne, une seule dose a été nécessaire. Quànt à ceux qui avaient reçu du diazépam ou du dropéridol, plusieurs doses horaires ont dû être administrées. Par voie intra-musculaire, l'action maximale de la physostigmine apparaît survenir entre 20 et 30 minutes après l'injection et dure de deux à quatre heures.

Lorsque les patients qui ont reçu les agents ci-haut mentionnés et des narcotiques présentent de l'inconscience mais respirent bien, on utilise de la physostigmine au lieu des antagonistes des narcotiques. Pour un patient comateux, on commence par donner $2 \mathrm{mg}$ par voie intra-veineuse, pour ensuite répéter des doses de $1 \mathrm{mg}$ jusqu’à ce qu'on obtienne l'effet voulu ou des effets secondaires. Seulement six de nos patients ont présenté des nausées et des vomissements. On n’a pas eu de problèmes de bradycardie. Des petites doses d'atropine, de glycopyrrolate ou de bromure de propanthéline peuvent être employées pour prévenir ou renverser ces effets secondaires. Dans notre série, ces effets secondaires n'ont pas été observés chez les patients qui avaient reçu des alcaloïdes de la belladonne, mais seulement chez ceux qui avaient reçu uniquement des tranquilisants.

Comme mise en garde, il faut mentionner un travail fait chez l'animal, qui sug. gère que la physostigmine peut potentialiser la somnolence occasionnée par les barbituriques ou les agents d'inhalation.

\section{REFERENCES}

1. Holzcrafe, R.E., Vondreli, J.J., \& Mintz, S.M. Reversal of post-operative reactions to scopolamine with physostigmine. Anesth. Analg. 52: 921 (1973).

2. OrR, R. Reversal of datura stramonium delirium with physostigmine: report of three cases. Anesth. Analg. 54: 158 (1975).

3. Greene, L.T. Physostigmine treatment of anticholinergic drug depression in post-operative patients. Anesth. Analg. 50: 222 (1971).

4. Duvorsin, R.C. \& KaTZ, R. Reversal of central anticholinergic syndrome in man by physostigmine. J.A.M.A. 206: 1963 (1968).

5. Young, S.E., Ruiz, R.S., \& Falletta, J. Reversal of systemic toxic effects of scopolamine with physostigmine salicylate. An. J. Ophthalmol. $72: 1136$ (1971).

6. Hussey, H.H. Physostigmine: value in treatment of central toxic effects of anticholinergic drugs. J.A.M.A. $231: 1066$ ('1975).

7. Cnowell, E.B. \& Kетснuм, J.S. The treatment of scopolamine-induced delirium with physostigmine. Clin. Phamacol. Ther. 8: 409 (1967).

8. Heiser, J.F. \& Gillin, J.C. The reversal of anticholinergic drug-induced delirium and coma with physostigmine. Amer. J. Psychiat. 127: 1050 (1971).

9. RuMack, B.H. Anticholinergic poisoning: treatment with physostigmine. Pediatrics 52: 449 (1973). 
10. Smiler, B.G., Bartholomew, E.G., Sivak, B.J., Alexander, G.D., \& Brown, E.M. Physostigmine reversal of scopolamine delirium in obstetric patients. Amer. J. Obstet. Gynecol. 116: 326 (1973).

11. Rosenberc, H. Physostigmine reversal of sedative drugs. J.A.M.A. 229: 1168 (1974).

12. Bernards, W. Case history 74: reversal of phenothiazine-induced coma with physostigmine. Anesth Anąlg. 52: 938 (1973).

13. Burks, J.S., Walker, J.E., Rumack, B.H., \& OTt, J.E. Tricyclic antidepressant poisoning. Reversal of coma, choreoathetosis, and myoclonus by physostigmine. J.A.M.A. 230: 1405 (1974).

14. SNyder, B.D., Blonde, L., \& McWhirter, W.R. Reversal of amitriptyline intoxication by physostigmine. J.A.M.A. 230: 1433 (1974).

15. Slovis, T.L., OTt, J.E., Teitelbaum, D.T., \& Lipscomb, W. Physostigmine therapy in acute tricyclic antidepressant poisoning.

16. El-Yousef, M.K., Janowsky, D.S., Davis, J.M., \& Sekerke, H.J. Reversal of antiparkinsonian drug toxicity by physostigmine: a controlled study. Am. J. Psychiatry 130: 2 (1973)

17. Granacher, R.P. \& Baldessarini, R.J. Physostigmine. Its use in acute anticholinergic syndrome with antidepressant and antiparkinsonian drugs. Arch. Gen. Psychiatry 32: 375 (1975).

18. Koelle, G.B. In The Pharmacological Basis of Therapeutics. 5th Ed., Goodman, L.S., and Gilman, A., Editors. Toronto. Collier Macmillan Canada, p. 455 ( 1975).

19. GreEn, V.A. Alterations in the activity of pentothal, phenobarbital, pentylenetetrazol, and strychnine by cholinesterase inhibitors. J. Pharm. Sci. 53: 762-766 (1964).

20. Mazel, P. \& Bush, M.T. Brain barbital levels and anaesthesia as influenced by physostigmine and epinephrine. Biochem. Pharmacol. 18: 579-586 (1969).

21. Seeman, P., Chau-Wonc, M., Tedesco, J., \& Wong, K. Brain receptors for antipsychotic drugs and dopamine: direct binding assays. Proc. Nat. Acad, Sci, U.S.A. 72: 4376 (1975). 